\title{
UNDERSTANDING THE MEDIA
}

A

t the risk of undertaking to teach grandmother how to suck eggs*, we'd like to put aside for a moment matters of science and policy to consider the proper use of a practical tool-the press. The Industrial Biotechnology Association (IBA) devoted the better part of its May meeting to discussing the pressrevealing in the process some real grievances, some differences of opinion, and a few perplexing misunderstandings of the nature of the media. Here, in any case, are some of the points we found ourselves mulling over in the wake of the IBA meeting:

- Is biotechnology somehow different from all other technologies? At the IBA meeting, Agrigenetics' David Padwa said no. He took exception to what he called "bioexceptionalism," a credulous, gee-whiz reflex that seems especially widespread in the lay press and the public it serves. Someday, said Padwa, the press and public will realize how boring biotechnology really is.

The market doesn't really care whether a product is produced by recombinant $E$. coli or by more traditional chemical synthesis-save, of course, that the process determines whether a product can be produced economically or, indeed, whether it can be produced at all.

Even among the experts, however-perhaps especially among the experts-persists the belief that we are onto The Real Thing here. They are unashamedly awestruck by the beauty, complexity, and sheer audacity of what they have undertaken.

The press and public are ready, even eager, to pick up and amplify that sense of wonder, unleavened by the expert's understanding.

Much of the perceived "bio-exceptionalism" is simply a crossbreeding of the national enthusiasm for medical subjects (the same wide-eyed rube eagerness for panaceas that kept the pockets of snake-oil pitchmen well lined through the last century and into this) with an equivalent enthusiasm for the new cargo cult of high technology. Given enough time and effort, it should be possible to educate the public and the press into an intellectual understanding of just what biotechnology means-and what it doesn't mean. Even then, however, we suspect that certain elements of biotechnology will strike chords of emotion beyond the reach of education.

Plagues are the great bogey of the popular imagination. They have a mythic dimension. From the Iliad to Camus, pestilence has been the dark field of visceral, unreasoning horror against which moralists have dissected and examined what is essentially human. This age-old and deeply rooted terror still lurks just below the skin of generations that have never seen a true plague, ripe for a novel by Crichton or King, or the bland speculation of a news service wire report. Whatever the technical window-dressing, fear of the pest is the wellspring of attacks on recombinant DNA research. Education might help, a bit,

*Why we should think to teach grandmother how to do this is beyond us. but the fear will remain for some time, even after experience demonstrates that the technology is safe.

Beyond the fear of Frankensteinian microbes may lie another fear. It seems to us that the ability to change the genetic makeup of an individual or a species undermines some of the foundations on which social mores and individual identity are based. And to touch these foundations is to tap the same vein of animosity that greeted Darwin and Huxley in the nineteenth century and continues in this century. If it is true that social codes have grown out of instincts evolved to preserve the species, and if we hint that we may someday be able to preserve individuals or species by changing them into something else again, then we have thrown the line of moral progression into a self-referential loop. And, we have divided the question of the meaning of individual life, for the individual's ability to survive is no longer really connected with the inheritance it passes to later generations.

If these are indeed the associations raised by biotechnology, we would suggest that no other technology-except perhaps for nuclear engineering-offers quite as much opportunity for popular misunderstanding. Add the potential for producing results that are unattainable by any other means, and it seems that biotechnology is indeed different from other technologies.

- All writers are story-tellers. Several executives at the IBA meeting had apparently been burned by the presswhether general, financial, or technical. Some complained of inaccuracy or unfairness when what was really at issue was presentation: the writers emphasized the wrong aspects of a story, or played it up too much. Writers don't always realize, and would not always care if they did realize, how vulnerable a business can be as it emerges from its venture-capitalized chrysalis. In general, journalists are taught that the truth comes first, and the needs of the people most involved with the story follow pretty far down the list. In between comes the need to tell the story in a way that will capture readers' imaginations. Dramatic incidents, conflicts, tensions, exciting possibilities-any journalist worth his or her salt will go after these every time. So writers inevitably raise their readers' superstitious fears, if only to put them to rest. It touches something deep in the audience, and helps guarantee that the piece will be read with attention.

- "Media" is plural. To believe otherwise is to commit an error of judgment as well as of grammar. Each publication and program has its own viewpoints, biases, likes, and dislikes. And within each publication, the writers are themselves distinguished by preferences and talents of their own. Some may know more about science than others; some may know finance; some may need a whole lot of teaching; some may be given to easy enthusiasm; others may be glacially slow to accept new ideas.

Even when carefully managed, dealings with the media can yield uneven results. In the long run, though, news coverage is a little like government-one gets the press one earns.
-Douglas K. McCormick 